\title{
Research Paper: Probing the Drivers of Housing Deficit in Ghana: A Fresh Scoping Review
}

\author{
Ibrahim Y. Wuni ${ }^{\star *}$, Henry K. Boafo ${ }^{2}$, M. Owusu-Yeboah ${ }^{3}$, Romanus D. Dinye
}

1. Postgraduate Student, Department of Civil Engineering, School of Energy, Geoscience, Infrastructure and Society, Heriot-Watt University, Edinburgh, United Kingdom.

2. Research Fellow, Centre for Settlements Studies, Kwame Nkrumah University of Science and Technology, Kumasi, Ghana.

3. Lecturer and Research Fellow, Centre for Land Studies, Kwame Nkrumah University of Science and Technology, Kumasi, Ghana.

4. Professor, Department of Land Economy, Kwame Nkrumah University of Science and Technology, Kumasi, Ghana.

$\begin{aligned} & \text { Use yourdevice to scan } \\ & \text { and read the artice online }\end{aligned}$
na: A Fresh Scoping Review. Journal of Sustainable Rural Development, 2(1-2), 3-16. https://doi.org/10.32598/jsrd.01.03.260
dol $:$ https://doi.org/10.32598/jsrd.01.03.260

Article info:

Received: 29 Dec. 2017

Accepted: 06 April 2018

Keywords:

Drivers, Housing Deficit, Policy, Ghana

\section{ABSTRACT}

Purpose: The study sought to identify the most reported relevant drivers of housing deficit in Ghana from empirical studies and to be guided by them to propagate practical micro and macro levels housing strategies that could be pursued by households, communities, and government to address the housing needs of both rural and urban households. The review makes a distilling contribution to the housing literature advancing the critical drivers of housing deficit and propagating the dire need for resilient housing remedies in Ghana.

Methods: The study adopted an exploratory research design and mainly reviewed relevant housing literature comprising of scholarly articles, research papers, policy documents, conferences proceedings and dissertations. A thematic content analysis was undertaken to facilitate the mapping out of the interconnected web of drivers of the housing deficit.

Results: The review of the literature indicated that housing deficit in Ghana is driven by a complex web of broad factors of demographic, financial, land, planning and policy drivers. It was also identified that previous research mainly focused on state-centred approach to the housing deficit and neglected the contributions and challenges of individual or community level housing delivery.

Conclusion: Mass social housing is resistant to policy interventions and national housing policies have failed to rescue the housing situation. Consequently, housing policy intervention should shift attention from state-centric housing model to individual or community level housing construction, largely because the interplay of the micro and macro level housing remedies have the capability of providing a resilient remedy to housing deficit in Ghana 


\section{Introduction}

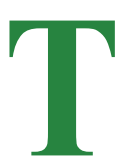

he availability of affordable housing is necessary for social security, sustainable development and intelligent urbanism (Boafo et al., 2017). The successful delivery of adequate and decent housing is an indicator of progressive socio-economic situations in a country (Giddings, 2007). Due to its significance, housing delivery will remain at the nucleus of social development and social policies in many countries, especially third world countries. Boehm and Schlottman (2001) emphasized the importance of housing and found that children whose parents were homeowners tended to achieve higher levels of education and income, have their own houses sooner, and accumulate more wealth than those with homeless parents.

Despite the necessary role of housing in stimulating socio-economic stability, housing deficit continues to rise beyond the sustainability of national efforts in Ghana. In the midst of pervasive unemployment, the impact of the great housing shortage is multiplied for vulnerable and low-income groups (Boachie-Yiadom, 2015). This is largely because their meagre income is divided to cover several living costs, including their housing cost. It is, therefore, no surprise that many of these groups live in sub-standard and temporary houses in Ghana. Housing deficit in that country is resistant to policy interventions, largely because the shortage continues to increase despite some policy interventions. Sadly, social housing has not received much attention in the past decade due to certain developmental challenges facing the limited national resources.

According to Ansah (2014), the housing is currently estimated to be suffering a deficit of 2.5 million units. Although this estimate is based on previous housing data and derived from the 2010 population and housing census, with some inherent errors, it does convey the magnitude of the housing problem in Ghana (Ghana Statistical Service, 2012). The estimate is plausible because there is a positive correlation between the population growth and the housing deficit in Ghana (Afrane et al., 2016). It is, therefore, only natural that the rapid population growth in the country continues to exacerbate the housing problem in spite of non-significant supply of housing. Even though policy makers and the government do realize the potential dangers that housing deficit poses to national economic development and social stability, the public appeals and policy interventions to slow down the crisis have clearly failed to bear any appreciable impact. With regard to these problems and the darker prospect of the future, it seems imperative to seek solutions to the situation.

The body of evidence from the existing housing deficit research suggests that Ghana's housing sector is dominated by private or individual developers who meet their housing needs through self-help, self-build and incremental housing. However, previous studies on housing mostly referred to the privilege of government housing policies over individual housing strategies. By this privileged government housing policies as reported in the literature, the researchers in this study have focused solely on the drivers of government housing policy failures in Ghana, while keeping silent on the challenges facing the individuals who still try to satisfy their housing needs despite the failure of government housing policies.

This paper makes the claim that the remedy to the housing deficit in Ghana lies in the recognition of the micro- and macro-level drivers of that problem. To this effect, the paper seeks to critically examine the plethora of empirical housing research available in order to identify the micro- and macro-level barriers to housing delivery and to propose some useful state-level and individual/ community-level solutions to the housing problem. The solutions will be based on the recognition that the interplay of macro (state-level) and micro (individual/ community-level) policies has engendered the resilient solutions to the housing deficit in Ghana.

The rest of the paper is organized as follows. Section two presents the review of housing literature in Ghana. Section three provides the research methodology. Section four outlines the findings from the literature in the appraisal and analysis of the issue. Section five provides brief and focused discussions of the findings and their implications. Finally, section six presents the conclusion and makes recommendations for policy adoption.

\section{Literature Review}

The literature on the housing problem in Ghana is reviewed with a focus on the analysis and critical appraisal of the drivers of that problem. The rationale for such a probe is to stimulate thinking about inclusive solutions to the problem.

\subsection{Drivers of housing deficit in Ghana}

The magnitude of the housing deficit in Ghana suggests that the housing sector is faced with numerous aggressive barriers or factors that individually or collectively exert adverse effects on it. 
To begin with, at the individual or community level, the challenges and barriers to the self-build and incremental housing have been reported to be at the top of the list of drivers, creating financial constraints and increasing land and property prices (Ansah, 2014). More pronounced in towns and cities due to the rapid urbanization, the situation is now a nationwide concern (Agyefi-mensah et al., 2011). The implication is that not only is self-help much threatened byl demands to purchase land, but the contribution of self-build and incremental housing to total housing delivery is also greatly crippled by the drastic shortage of construction skills among the citizens (Teasdale et al., 2009). The impact is multiplied in rural housing. The lack of skills means that individuals would have to pay hugely for the services of a limited number of building experts; the fees are sometimes beyond the economic status of many rural folks. Hence, self-build and incremental housing will be greatly enhanced if the number of skilled construction experts increases. This capacity building can affect both rural and urban housing, which contributes to the housing development nationwide.

Lack of individual/community level housing support has been reported to be a barrier to self-build and incremental housing developments (Djokoto et al., 2014). In the absence of social housing in the past couple of years, there has been renewed recognition of self-build and incremental housing in Ghana, notably among lowto-average income groups (Agyefi-mensah et al., 2011). Their efforts have been futile due to poor access to financial resources and the erratic pattern of their income flow (Bank of Ghana, 2007). Since individual house construction contributes to available national housing stock, the lack of support to augment the initiatives in this case has led to long delays in completing house construction projects and, consequently, to nationwide housing deficit.

Another driver of housing deficit in the complete absence of social housing has been reported as the high cost of building materials (Djokoto et al., 2014). This has raised the cost of construction for those involved in self-build and incremental housing as well as those in private housing delivery. The consequence is the high cost of privately delivered houses beyond the financial capability of vulnerable groups and incredible 'forever' delays in the completion of self-build and incremental housing projects. Wakely \& Riley (2011) reported that individual efforts in incremental housing and expansion of slums are also affected by the high cost of building materials. It is more pronounced due to the non-avail- ability of small-scale funds to support those activities (Derban et al., 2002).

The above-mentioned pitfall actually poses a barrier to house delivery at a micro level by slowing down the response of individual and community-level house constructors to house demandants, which consequently drives the housing deficit at the national level. Now, as it follows, it will be of insight to examine the state-level drivers of housing deficit in Ghana.

In the first place, the housing deficit in Ghana is said to be largely influenced by inherited long-standing shortage (Kwofie et al., 2011). This is plausible if considered from the perspective of a few years right after the independence, but, considering that Ghana has lived 60 years after the independence, this claim is hardly defendable. Although the impact of the colonial housing deficit on the current shortage is important, it cannot be over-stressed in the post-independence era. This is because, after independence, some nations have been able to optimize the use of their available resources to address their housing needs. Ghana, too, should have been capable of addressing its sever housing shortage using the available resources.

Housing deficit has also been reported to be driven by rural-urban migration (Todd, 2007; Afrane et al., 2016). Admissibly, Ghana is beset by a staggering high rate of rural-urban migration in quest of better life conditions in towns and cities. However, the exodus of people from rural to urban areas cannot be justified as a driver of the nationwide housing deficit; rather, it is noted for driving the urban housing shortage nightmare. In support of this, Boamah (2010) reported that rural-urban migration is a giant recipe for the aggravating urban housing shortage in Ghana. Therefore, rural-urban migration exerts pressure on urban housing and creates conditions where urbanites outnumber the available urban housing stock. To this effect, rural-urban migration only shifts the emphasis of the deficit from one area to another. As realized in the present study, beside rural-urban migrations, immigration into Ghana can account for housing deficit as well.

Afrane et al. (2016) and Ukwayi et al. (2012) reported that rapid population growth and urbanization account for the severity of housing deficit in Ghana. They argued that house delivery in Ghana is not moving in tandem with the rate of population growth and urbanization. Thus, demand becomes more than supply, leading to a deficit. This is very critical because the impact of population growth on housing deficit becomes greater where 
the growth faces a stagnant supply of houses. Indeed, this is justifiable in Ghana because social housing has been halted for about a decade now. When coupled with the inability of the exploding population to afford expensive private houses (Bank of Ghana, 2007), the inertia introduced into the housing industry only increases the deficit. This driver has been reported by Adebayo (2005), Nicole et al. (2010), and Boamah (2010). According to the existing evidence, Afrane et al. (2016) established that there is a positive correlation between rapid population growth and housing deficit in Ghana.

The UN-Habitat (2011) reported that the high cost of houses is the giant factor escalating the housing deficit in developing countries, including Ghana. This factor has been reported in nearly all the reviewed articles because affordability is at the core of house acquisition, especially in third world countries. The exorbitant cost is driven by the high cost of building materials (Afrane et al., 2016), emanating from the reliance on the imported building materials for house construction in Ghana. The additional profit margins that private developers include in the cost of production lead to prices far beyond the financial capability of the vulnerable (Bank of Ghana, 2007). The cost is exacerbated by the untenable continuous increase in land prices on grounds of discretion for future (Yeboah \& Obeng-Odoom, 2010). Practically, when the income of the vulnerable groups is juxtaposed against the current land prices in the provincial capitals and the surrounding towns, it becomes quite impossible for them to even afford the land, let alone to make a building on it.

It is, thus, not surprising that Boachie-Yiadom (2015) found that the low- and average-income groups account for the major segment of the homeless in Ghana. Recounting the affordability enigma in Ghana, Nenova (2010) reiterated that about $65 \%$ of the Ghanaian population cannot accommodate themselves without support from financial institutions or the state. Kwofie et al. (2011) echoed that only less than $15 \%$ of the Ghanaian population can afford house ownership, and less than $8 \%$ can afford it without mortgage. This means the orientation of social housing policies should be on rental housing rather than homeownership. This is because affordability is the greatest challenge for the hopeless majority (low- and average-income groups) (Flavin and Yamashita, 2002; Sinai and Souleles, 2005).

Closely related to the high cost of housing is the poor access to financial resources (Appiah-Kusi, 2014). This presents a challenge to homeownership through selfbuild or purchase of privately delivered houses. This driver is readily noticeable among the low-income earners and the vulnerable, whose infinitesimal income levels render them incapable of having access to financial supports. This is because of concerns for repayment sources and, consequently, translating it into their inability to raise enough funds to either build or purchase a house (Bank of Ghana, 2007). Besides, Ghana is characterized by inadequate mortgage financing (Afrane et al., 2016), pigeonholed by a natural restricted access due to the associated high interest rate and administrative bureaucracy in the arrangement of mortgage loans for house constructions. The financial system is also characterized by a high mortgage-to-income ratio, practically making the low income earners incapable of getting access to loans (Bank of Ghana, 2007).

Currently, as regretted by Bawumia (2017), Ghana has the highest mortgage-to-income ratio on the globe, making it practically difficulty for people to pay for mortgaged houses in the country. As in March 2017, the average mortgage interest rate in Ghana was from 33.8\% to $40.3 \%$ (Ayorkor, 2017). This is quite unattainable for the low-income earners who have no reliable sources of income. It should be reiterated that, even in the midst of the housing deficit, houses are being advertised for sale on a daily basis, indicating that affordability is the major driver of the homelessness. This signifies the economic and physical nature of housing deficit in Ghana. It is, therefore, not surprising that the homeless citizens are mostly within the low- and average-income brackets (Bank of Ghana, 2007).

Regarding the high cost of housing, Afrane et al. (2016) reported that the high price of land is one of the causes of the astronomical increase in the housing deficit. Undoubtedly, land is required for the construction of houses, and when the cost of acquiring it is too high, it becomes financially difficult for low-income earners to purchase land, let alone to do construction on it (Lemo, 2007). It has been noted that Ghana has historically incurred staggering increase in land prices due to a sense of speculation and discretion for future among land owners, buyers and real estate developers (Ubink \& Quan, 2008; Yeboah \& Obeng-Odoom, 2010). Also, the commodification of land in hitherto known urban fringes, largely driven by urbanization, has increased its value, making it difficult for the financially challenged to acquire a piece (AppiahKusi, 2014). The connection between the high cost of land and housing deficit is defensible in Ghana because home ownership is the focus of most citizens due to discontentment with rental housing. 
The land price issue is worsened by the problematic land administration, boundary disputes, land litigations, land grabbing and injunction on land development (Ubink \& Quan, 2008). Similarly, Afrane et al. (2016) further stated that multiple sales of land, land racketeering, uncertainty over the ownership of land, long delays in approvals and issue of titles, indiscipline in the land market, lack of compliance with planning requirements and corruption among land officials have posed extra hurdles to getting land for house construction in Ghana. This has introduced the planning component into the housing deficit. Although it is not pronounced, its contribution to the housing shortage cannot be overlooked. Boabang (2015) reported that a defective land tenure system exists in the wagon of land factors that have caused housing deficit in Ghana.

Afrane et al. (2016) reported that lack of continuity in the implementation of housing policies due to frequent government turnovers is a major driver of housing deficit. They emphasized that the failure of successive governments to continue housing projects initiated by previous governments accounts for the aggravating state of housing deficit in Ghana. They cited a prototypical example of the National Democratic Congress' (NDC) abandonment of 100,000 affordable housing units in 2009, initiated by the New Patriotic Party (NPP) in 2005. It should be realised that 4-year re-elections and change of governments alone cannot be considered as a reason because, since 1992, all the political parties that ever ruled completed eight years of governance. Besides, there are several other countries in the world that have practiced the same political system but have made significant achievements in house delivery. The problem seems to be due to the existence of partisan housing agendas rather than national housing agendas. Until 2015, there was no established national housing policy in Ghana (Ministry of Water Resources, Works and Housing, 2015). The seemingly political rivalry between the two major parties in Ghana has resulted in less attention to housing policies enacted by the NDC government; the current ruling party is the NPP. Expectedly, housing is not a major priority in their development agenda.

Besides, the 1992 constitution of the Republic of Ghana provides a leeway for potential non-performance of governments in house delivery. As stated by the provision in Chapter 6, Article 35 (7) of the constitution, "As far as practicable, a government shall continue and execute projects and programmes commenced by the previous governments" (Government of Ghana, 1992, pp. 33). Apparently, this provision does not make it obligatory for the projects to be continued by the suc- ceeding governments and expectedly does not spell out the consequences of discontinuity, thereby providing a back-door for succeeding governments to abandon previous housing projects with impunity. A constraint added to this poor performance is the ineffective implementation of housing policies (Appiah-Kusi, 2014). It can be argued that the discontinuity syndrome is attributable to the insufficient funds available to governments, but, considering that Ghana is richly endowed with economic resources, it is hardly justifiable that the housing policy enforcement deficiencies be linked to insufficient funds. The setbacks can be traced to corruption and embezzlement of funds in the implementation process (Kwofie et al., 2011).

Finally, Ukwayi et al. (2012) reported that housing deficit is on the rise in the country because Ghana lacks the political will to implement housing policies. The available evidence suggests that Ghana lacks both administrative and technical manpower to implement national policies (Boamah, 2010), and this is manifested in the inability of Ghana to sustain the previous housing policies, resulting in the country's inability to build the required number of houses for the ever-increasing population (Sodeinde, 2011). While this is closely tied to the implementation deficiencies in the country, it is more justifiable to argue that the implementation of housing policies is characterized by corrupt and uncultured practices, rather than lack of manpower and technical expertise. This is because the construction and real estate industry can handle housing within the policy framework, but it might not be sustained because of the associated misuse of allocated funds. Sadly, the country has also proved to be incapable of relying on public-private partnership so as to effectively address the housing crisis (Makinde, 2014). This is because the country has not provided an enabling environment as a prerequisite for private developers to fulfil their role in the house delivery discourse (Vuyisani, 2003; Mukhtar, 2005). Mass social housing has also been compromised in Ghana despite its being a panacea to the large housing deficit.

\subsection{Appraisal of the reviewed literature}

To sum up, it can be realized from the foregoing literature review that housing deficit is caused by a host of factors which can be categorized into land, financial, planning, policy and demographic drivers. Therefore, any commitment to quell or eradicate the housing deficit problem entails the careful consideration of all these drivers and certain minor factors. Indeed, a feasible solution to the housing deficit is based on the ability to build on tested and time-honouring policies and principles. 
Such tested policies and principles must be superimposed on sustainable national systems which would outlive any political party.

\section{Methodology}

The purpose of the study is to critically appraise the plethora of empirical research findings about housing deficit in Ghana, to identify the most reported and relevant drivers, and to propose remedies to the drivers of the housing problem. According to the convention of scholarly writings, the study started with a literature survey to collect data relevant to the topic. The search was facilitated by the use of databases such as Scopus, Web of Science and Google Scholar. Keywords and phrases such as "housing deficit in Ghana", "housing in Ghana", "housing delivery" and "factors causing housing deficit in Ghana", together with "document type" and "year of publication" were used to filter the relevant data.

Although publications in the last five years are deemed recent for scholarly writings, this study included scholarly articles, research papers, conference proceedings, dissertations and policy documents published from 2001 to 2017. The rationale was to have a wide coverage of the advances in housing research in Ghana. The paper adopted an exploratory research design, employed within a qualitative methodological paradigm. Recognizing that the interpretation of qualitative data within the constructivist research paradigm can be biased (Yin, 2003), efforts were made to ensure objective critiques on every reviewed document. The exploration and the review were carried out from September 2017 to December, 2017. Apart from the policy documents, the reported drivers were critically considered to ascertain their influence on housing deficit, based on the current national dynamics and the relevance and frequency of the reports. Although the drivers reported in the literature review in this study are not ranked, they are the most widely reported ones in the literature.

\section{Findings}

In this section, a conceptual classification is provided of the drivers. The rationale is to summarize and categorize the various drivers of the deficit into major groups for policy considerations. In fact, the drivers of the housing deficit reported in the literature can be broadly categorized into demographic, financial, land, planning and policy drivers.

\subsection{Macro- and micro-level drivers of housing deficit}

The Figure 1 displays the macro- and micro-level factors fuelling the increasing magnitude of the housing deficit in Ghana.

The Figure 1 summarises the evidence from the literature review. The state-level drivers of housing deficit are categorised into demographic, financial, land, planning and policy drivers. The key demographic drivers as reported in the literature include rural-urban migration (responsible for urban housing crisis), immigration, and rapid population growth. However, considering the housing deficit on a national scale, only the population growth and immigration have been reported several times in the literature (Afrane et al., 2016). Also, the factors that are related to housing finance at the individual or national level are grouped as financial drivers. The review of the literature exposed unaffordability as the central financial driver of the housing deficit (Appiah-Kusi, 2014; Wapwera et al., 2014), which brings about several disadvantages with different degrees of magnitude to low-income and vulnerable groups (Bank of Ghana, 2007; UN-Habitat, 2011).

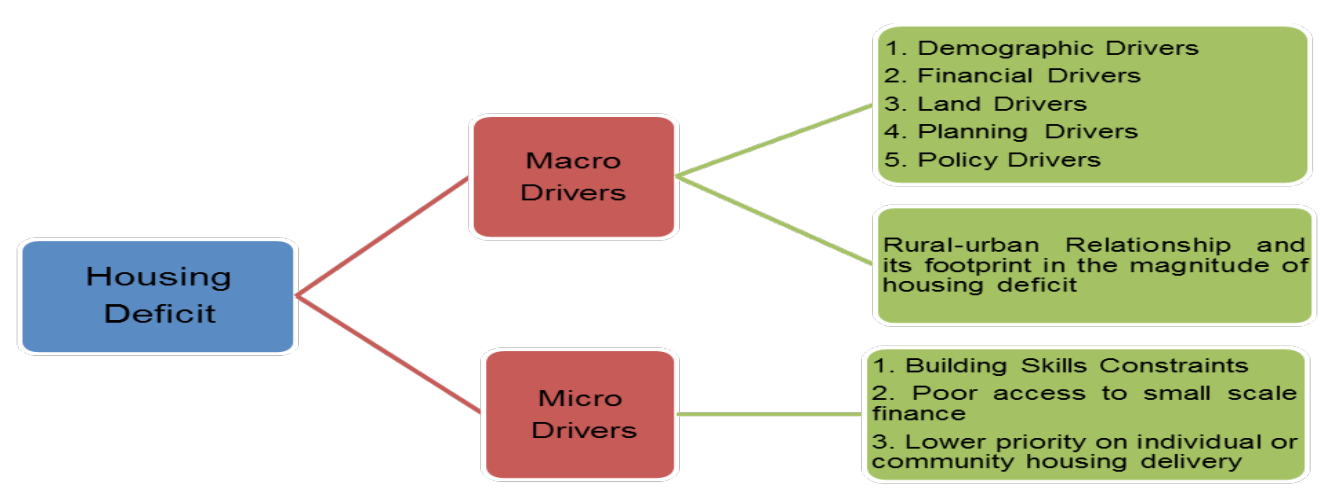

Figure 1. Macro- and micro-level factors driving the housing deficit in Ghana. Source: Authors' Construct 2017 JSRD 
Land drivers are the threats and barriers presented by access to land for house construction or delivery. Although cost components can be included in financial drivers, the economics of land for housing delivery warrants it to be treated distinctly in analyses (Ubink \& Quan, 2008). It should be realised that, when the difficulty in obtaining land for house construction is combined with the inelastic supply nature of house delivery in Ghana, the influence of land drivers becomes very pronounced and intense (Ubink \& Quan, 2008; Yeboah \& ObengOdoom, 2010). Furthermore, the barriers to housing delivery associated with planning permission, development controls and zoning requirements are classified as the planning drivers of housing deficit. Although most of the literature does not emphasize the planning factors of housing shortage in Ghana, these factors contribute to the rising trends of the deficit (Nicole et al., 2010).

Notably, policy drivers emerge as perhaps the most critical when examining the social housing paradigm and trajectory. These drivers are barriers to housing delivery and are closely related to the influence of policies on housing delivery. They actually account for social housing policy failures in Ghana (Kwofie et al., 2011).

Finally, barriers to individually or privately delivered housing are classified as micro-level drivers of housing deficit. Although there is an inseparable connection between the drivers outlined above and the micro-level drivers, they are separated in this review for the analysis of nuances. Individual financial challenges have been reported as a major barrier to individual housing construction.

The Table 1 provides a summary of the manifestations of various drivers of the housing deficit in Ghana. The lists are not exhaustive for individual drivers but present the widely reported forms that each driver takes.

\section{Discussion}

As it can be noticed from the findings, housing deficit in Ghana is driven by a complex web of connected factors. Starting with demographic drivers, Ghana has a relatively high rate of population growth, which makes it hard to provide for all the social needs. Also, immigration is on the rise due to the relatively unrestricted entry from the neighbouring countries. Owing to the peaceful and liberal nature of the country, most immigrants find Ghana as a safe destination in times of tension in their origin countries. The combination of rapid population growth and high rate of immigration is naturally expected to increase the number of people competing for the nearly fixed housing stock. When these combine with the lack of response or the slow response of the housing sector to demands, the result is but a sharp increase in the housing deficit (Ansah, 2014). Although the population growth and the increased immigration are not the direct drivers of the deficit, the inability of the housing sector to respond to the increased demand bears an indirect impact on the housing deficit. Also, with the projected chances of increased urban population in Ghana in 2030 and beyond, the housing deficit will be driven greatly by the demographic factors (Department for International Development (DfID), 2015). When this projected increase is coupled with the increasing levels of poverty and unemployment in the country, slums and casual settlements are likely to increase (ibid).

Furthermore, house construction either by the state or by individuals requires funds for the purchase of land and construction materials, maintenance, renovation, and/or the payment of rents. Unfortunately, about $68 \%$ of the Ghanaian population is at low-to-moderate income levels and cannot afford houses with basic standard services without financial supports (Bank of Ghana, 2007a). Also, the so-called 'affordable houses' delivered in Ghana are not affordable to the majority of the citizens, especially in urban areas (Boamah, 2010). The influence of microfinance on small-scale housing delivery has not been great enough to alleviate the financial limitation for individual housing delivery (Derban et al., 2002). Consequently, in the face of the drastic housing shortage, moderate-to-low income earners are sheltered in poorly developed and dilapidated housing units (DfID, 2015). The unaffordability of houses is the topmost factor in the housing deficit, which has rendered the contribution of private developers very slow. Similarly, due to the high interest rate and 'aggressive' payment terms associated with the inadequate mortgage system in Ghana, access to housing finance is practically limited for the low- to moderate-income earners, who cannot afford to repay the loans and the interest on them (Bank of Ghana, 2007a; Griffith \& Jefferys, 2013). It is, therefore, not surprising that incremental and self-built housing currently dominates the housing sector.

Self-built and incremental housing is threatened by inherent financial barriers. The manifestation of this effect is that self-built and incremental housing practices and projects are incredibly delayed, and the completed houses are poorly maintained (Yorgri et al., 2016). Therefore, the financial drivers have contributed to both the quantity and the quality of deficit across the rural and urban areas (DfID, 2015). With the high cost of building materials, the financial drivers leave the low- to average-income 
groups to the mercy of poor-quality building materials. In this regard, in order to house low- to average-income groups, there is a need for a "pluralistic approach that stresses enabling housing provision for the poor by expanding the range of providers to include government, the private sector, the poor themselves, non-governmental agencies, and cooperatives" (Yeboah, 2005).

Moreover, land drivers contribute to housing deficit by serving as barriers to land access. The complicated land rights in Ghana pose a major challenge to housing. Apart from the fact that rapid urbanization has increased land prices in nearly all the regions of the country, it has been reported that the continuous rise in land prices is largely driven by speculation or discretion for future (Yeboah $\&$ Obeng-Odoom, 2010). The situation is worsened by the indiscipline in the land market, land racketeering, uncertainty over land ownership, problematic land administration and the 'predatory' attitudes of land sale by traditional rulers (Ubink \& Quan, 2008). The knock-on effect is that even individuals who embark on the self-built and incremental housing approach have to deal with several levels of bureaucracy and unclassified corruption ranging from public officials to real estate agents through to traditional rulers. The amount of money required to even start the negotiations for the purchase of land might be equivalent to the amount that can be used to raise a number of blocks in the anticipated housing. This limits the impact of self-build and incremental housing delivery. It also increases the cost of houses delivered privately for sale. It generally results in a serious barrier to housing delivery and/or unaffordable prices of housing.

With planning drivers in focus, housing deficit is driven by unnecessary planning restrictions and delays in the approval of planning permits. Although the influence of the planning drivers is not highly pronounced, they pose barriers to housing delivery. This is because there is a growing trend of corruption in the planning process of housing in Sub-Saharan Africa, particularly, Ghana and Nigeria (DfID, 2015).

The political and policy drivers make up the state-centric housing delivery barriers. It is quite safe to claim that there is no successful social housing policy recorded in Ghana. Consequently, social housing in Ghana is resistant to policy intervention. The conventional arguments presented in line with the policy barriers are the late arrival of the national housing policy, ineffective policy implementation mechanism and associated corruption in the implementation process (Kwofie et al., 2011). These arguments make it appear as if the mere existence of a national housing policy would automatically address the housing conundrum, while there are a number of sectors with national policies that even cannot be described as satisfactory. Although their claims are quite plausible, there is no quick-fix solution to these barriers because the political split in the country has turned every national policy into a partisan one; every national policy is enacted during a particular political party's administration. To this effect, despite the implementation of the national housing policy in 2015 , there has clearly been no positive impact of that policy on the housing deficit. The implication of this is that state social housing cannot thrive in Ghana in the midst of corruption, partisan perceptions of policies and embezzlement of funds in implementation processes. Therefore, the public private partnership, if properly implemented, could be a panacea to the inherent policy barriers to housing delivery in Ghana though this partnership would be politically motivated and affected directly or indirectly by policy implementation deficiencies. Therefore, to encapsulate individual or community level initiatives, a panacea to the housing deficit should focus on remedies beyond the state level.

\section{Conclusion and recommendations}

\subsection{Conclusion}

It is evident that housing deficit in Ghana is driven by a complex web of demographic, financial, land, planning, and policy factors. Each or a combination of these factors pose certain barriers to housing delivery in the country. It is to be noticed that social housing policies have failed to attain their national objectives, and social housing is currently resistant to policy interventions in Ghana. The housing units described as 'affordable' have proved to be unaffordable to urban citizens in that country. However, in the midst of government housing policy failures, individuals and private developers have managed to slowly build houses. This implies that housing policy interventions should make a paradigmatic shift of focus from state-centered housing to individual/ community-level housing discourse. The attempts and the ability of individuals to satisfy their housing needs within the government housing policies crisis reflects the inherent resilience of Ghana's housing sector. Therefore, the interplay between the macro (state-level) and the micro (individual/community-level) housing remedies can serve as a key to engendering resilient remedies to the housing deficit problem. Consequently, lessons from the gradual individual success should be taken and intertwined with state-level remedies if practical and resilient remedies are to be propagated to housing deficit in Ghana. 
Table 1. Manifestation of the drivers to the housing deficit in Ghana

\begin{tabular}{|c|c|}
\hline Specific Drivers & Manifestations/forms \\
\hline Demographic drivers & $\begin{array}{l}\text { - Influence of high birth rate } \\
\text { - } \quad \text { Increasing rate of immigration } \\
\text { - } \quad \text { Aging and death rate } \\
\text { - } \quad \text { General lower-income levels } \\
\text { - High rate of rural-urban migration } \\
\text { - } \quad \text { Rapid population growth }\end{array}$ \\
\hline Financial drivers & $\begin{array}{l}\text { - High cost of housing (both self-build and purchase) } \\
\text { - } \quad \text { Poor access to financial resources } \\
\text { - High mortgage-to-income ratio } \\
\text { - High cost of building materials }\end{array}$ \\
\hline Land drivers & $\begin{array}{l}\text { - High cost of land due to commodification } \\
\text { - Unresponsive land tenure systems } \\
\text { - } \quad \text { Land litigations and boundary disputes } \\
\text { - } \quad \text { Problematic land administration system } \\
\text { - Uncertainty over ownership of land } \\
\text { - Long delays in approving \& issuing titles } \\
\text { - Indiscipline and corruption in the land market }\end{array}$ \\
\hline Planning drivers & $\begin{array}{l}\text { - Unjustifiable long delays in issuing development and planning permits } \\
\text { - Unnecessary injunctions on development lands } \\
\text { - Poor zoning regulation and implementation deficiencies }\end{array}$ \\
\hline Policy drivers & $\begin{array}{l}\text { - 'Late' arrival of the national housing policy } \\
\text { - } \quad \text { Accompanying unsatisfactory implementation } \\
\text { - } \quad \text { Partisan aspect of housing policies } \\
\text { - Lack of continuity of housing projects by political parties } \\
\text { - Embezzlement of social housing delivery funds } \\
\text { - Corruption in the implementation of housing policies }\end{array}$ \\
\hline $\begin{array}{l}\text { Footprint of rural-urban migration } \\
\text { relationship }\end{array}$ & $\begin{array}{l}\text { - Increased pressure on urban housing } \\
\text { - } \quad \text { Reduction rural building artisans } \\
\text { - General reduction in human capital for rural housing delivery }\end{array}$ \\
\hline Micro drivers & $\begin{array}{l}\text { - Lower income levels of rural folks and poor access to small-scale financial support } \\
\text { - } \quad \text { Lack of technical support for individual or community slum upgrading } \\
\text { - Lack of financial and technical support for self-built and incremental housing initiatives } \\
\text { - Inadequate population of rural building artisans }\end{array}$ \\
\hline
\end{tabular}




\subsection{Tentative policy recommendations}

The focus of the paper is on probing the drivers of housing deficit so as to recommend micro- and macrolevel remedies to improve housing delivery in Ghana. Based on the outcomes of the literature review and the anticipated drivers of housing deficit in the future, the following tentative remedies are suggested as housing strategies to be pursued by households, communities, and governments. These strategies, indeed, target the housing needs of both rural and urban households.

\subsubsection{Micro-level remedies}

These remedies are branded micro-level because they are specifically meant to facilitate and promote housing on small scales by individuals and community groups. The authors, of course, recognize that it is the sum of individuals and communities that make up a nation.

- Self-help, self-build and incremental housing should be given greater recognition, and capacity building should be undertaken at district and regional levels. This should be fulfilled through teaching individuals and communities the improved ways of expediting housing delivery. Assemblymen and community leaders can spearhead these initiatives and seek technical and financial support from district and regional officials.

- Microfinance is getting easy to access in all the regions in Ghana, but it should be harnessed and dedicated to small-scale housing to support individuals or community groups that seek to make their own houses. This initiative can be best implemented if it receives a national recognition and is supported by the Bank of Ghana.

- Laterite and resilient 'atakpame' buildings should be improved to meet the planning standards and to facilitate rural housing. Assemblymen and community leaders should be at the forefront of this development to ensure that the benefits reach the rural housing industry. Also, the use of local materials in house construction should be encouraged.

- Slums should be upgraded so as to make the best use of the land where dilapidated structures are currently situated. Old complexes and temporary structures should be upgraded to increase the housing capacity per unit area. Land readjustment approaches would be very useful in this regard. This should be nationally recognized and supported by community groups to ensure that land owners and/or house owners are given a fair share in the development.

\subsubsection{Macro-level remedies}

Recognizing that the interplay of state-centered and individual-level housing remedies can facilitate housing delivery and alleviate housing deficit, the following macro-level remedies are proposed:

- The first and foremost state-level remedy is the shift of emphasis from mass national housing to providing support for individual or community-level housing. This is very promising because, in the midst of the consecutive trends of government housing policy failures, individuals and private developers manage to slowly build their own houses. Therefore, given sustained significant efforts, housing delivery by individuals could greatly contribute to the improvement of housing deficit.

- It should be clearly recognized that the mere existence of national housing policies cannot affect the deficit, unless those policies are implemented in practice. Also, the policies should be improved and made comprehensive enough to outline clear targets and assign roles to all concerned stakeholders and mechanisms for achieving the targets. Although tentative, an independent national implementation directorate should be constituted, devoid of any partiality, influence or interference. This body should also be given a budget allocation to achieve the already set targets and be made aware of the consequences of their failure. This might be aggressive, but there should be no room for failure if the policies are expected to be of impacts.

- It appears housing is not a major priority in the incumbent government. Therefore, it should be made a priority in the national development agenda, backed up by strict legal provisions and respected by all political parties. The authors do recognize that every political party often comes with its development agenda, which is mostly its priority, but housing should be made a national priority which must be given due recognition by any ruling party.

- Considering that social housing is resistant to policy interventions, public private partnerships should be strengthened to improve the housing delivery. The national policy on Public Private Partnership, enacted in 2011, could be utilized to achieve this improvement. One feasible option is to prioritize the old idea of masshousing, but, in modern times, it should be focused on prefabricated houses meant solely for rental purposes. The houses to rent should be pro-poor, to ensure that very poor citizens can afford the monthly rent. Prefabricated houses should be constructed by the members of Ghana Real Estate Developers Association (GREDA) and su- 
pervised by the government, devoid of corruption and political interferences. Choosing GREDA means that the members can easily be called to order in the event of failures. Indeed, it should be deemed as a national crime for any government official to take up or purchase any of those houses. This is to ensure that the houses do not end up in the hands of rich politicians, ignoring the poor Ghanaians.

- At the national level, governments should increase the budget appropriation for the proposed prefabricated mass rental housing. In this case, construction banks should be established to invest the required funds to avoid cost overruns in the execution of projects. Portions of these funds should be devoted to assisting individuals and community-level housing initiatives nationwide.

- The Bank of Ghana should undertake development of certain housing finance mechanisms through setting up mortgage markets. At the current level of interest rates, the mortgage-to-income ratio is unacceptably high for the financial capability of the low-to-average income groups. These people make up a larger proportion of the homeless (Bank of Ghana, 2007b). Improvement of mortgage arrangements can reduce the associated bureaucracies and improve the access to financial support. Also, there should be capacity building and financial support for microfinance companies. These companies should establish community-based housing finance schemes to support individuals and groups at the community level towards self-help, self-build and incremental housing.

- The implementation of policies in land, planning and housing should be given a renewed recognition. It has been noted that Ghana has one of the best sets of laws in Africa, and, yet, has the poorest record of policy implementation there (DfID, 2015). Therefore, if the laws and policies are enacted and not well implemented, it is natural that they will only worsen the reason (s) for which they have been enacted. The Land Administration project which was started in 2003, the Land Use and Spatial Planning act (Act 925) and the Land Bill (2016) have the potential to relieve the land and planning drivers connected to the housing deficit. However, if these, together with the national housing policy, are not given due implementation and enforcement, no improvement should be expected in the areas for which they were enacted. The need to address the anthropogenic aspect of policy implementation should be given a national focus. Housing policy practitioners should be made aware of the inextricable link between housing and national socioeconomic stability as well as the need to prioritize the national interest in the implementation of housing policies.

- The government should improve the rural economies using the one-district-one-factory policy to create jobs in villages to regulate the rural-urban migration. The authors recognize that people take a resort to rural-urban migration for several reasons; for some of them, there is no encouraging level of development to make them stay in their rural areas. In this case, integrated rural development through the creation of jobs, development of better schools, provision of basic amenities, and improvement of social life is likely to discourage rural-urban migration to a great extent. This would improve the overall urban housing situation.

- Gradual birth control measures, preceded by conscious commitment to encourage family planning, are highly potential to regulate the population in Ghana. Even in the absence of this policy, there is an increasing natural inclination to support birth control. This is because people are beginning to regulate their child birth due to the tough economic situation in the country in recent years (Bank of Ghana, 2007). This should be accompanied by improvement in Ghana's immigration system to regulate excessive immigration.

- The final macro-level remedy addresses the government; it should improve the economy so as to enable people to generate adequate income to pay their rents or initiate and complete their incremental and self-built houses. Although the remedies have simply been enumerated in this research, the authors are confident that these propositions will collectively form a basis for effective micro- and macro-level commitments to addressing the housing deficit issue.

\subsection{Areas for further research}

Based on the review made in this study, the following areas are identified as viable for further research with a focus on proposing solutions to the housing deficit in Ghana:

- Lessons taken from gradual, individual successes in self-build and incremental housing and their improvement by research findings on housing policies

- Focusing on ways of promoting self-build and incremental housing as well as upgrading slums into high-rise buildings to provide shelter for larger groups 
- Affordable rental housing and enactment of policies to ease affordability constraints and alleviate homeownership concerns.

- Examination of the complicated reality of land rights and its intersection with the day-to-day life experiences of households that are in need of housing in Ghana.

\section{Acknowledgements}

This research did not receive any specific grant from funding agencies in the public, commercial, or not-forprofit sectors.

\section{Conflict of Interest}

The authors declared no conflict of interests.

\section{References}

Adebayo, O. (2005), "Marketing and Firm Survival in Nigerian Economy". PR, Advertising and Marketing Journal, Vol.4, No.2 pp.12-20

Afrane, E., Ariffian, A., Bujang, B., Shuaibu, H., \& Kasim, I. (2016). Major Factors Causing Housing Deficit in Ghana. Journal of Developing Country Studies, 6(2), 139-147.

Agyefi-mensah, S., Post, J. M., De Ligny, E. W., Van, E. L., Mohammadi, M., \& Badu, E. (2011). Towards Sustainable Housing Solutions for the Low/Moderate Income Group in Ghana: Policy Change or Design Innovation? In 8th Annual European Real Estate Society Conference in Eindhoven, the Netherlands (pp. 1-8). Retrieved from https://eres.architexturez.net/system/files/pdf/eres2011_350.content.02696.pdf

Ansah, S. K. (2014). Housing deficit and delivery in Ghana : intervention by various Governments. International Journal of Development and Sustainability, 3(5), 978-988.

Appiah-kusi, G. (2014). The Role of the Informal Sector in Housing Provisioning in Kumasi. (Published M.Sc Thesis). Kwame Nkrumah University of Science and Technology, Ghana.

Ayorkor, A. J. (2017). Average mortgage interest increases to 33.8\% in March. Accessed on 9/6/17 at http://citibusinessnews.com/index.php/2017/04/24/average-mortgage-interest-increases-to-33-8-in-march/

Bank of Ghana. (2007). The Housing Market in Ghana. Research Department, Bank of Ghana, Accra, Ghana, 1-46.

Bank of Ghana. (2007a). The Housing Industry in Ghana: Prospects and Challenges-Policy Brief June 2007. https://doi. org/10.1177/0022146512469014

Bank of Ghana. (2007b). The Housing Market in Ghana. Accra, Ghana. Retrieved from https://www.bog.gov.gh/privatecontent/Research/Research Papers/bog housing.pdf
Bawumia, M. (2017). Ghana's Mortgage Cost The Highest In The World - Dr. Bawumia. Accessed on 9/6/17 at http://www. thecophq.org/expo_religlobal.php?id=3385

Boabang, J. (2015). Residential Mortgage Finance; A Solution to Housing Deficit Challenge in Ghana, (July), 90.

Boachie-Yiadom, E. K. (2015). Assessing the Role of Mortgage in Private Housing Finance in Ghana: a Case Study of Kumasi Metropolis of Ghana. (Published M.Sc. Thesis). Kwame Nkrumah University of Science and Technology, Ghana.

Boafo, H. K., Wuni, I. Y., \& Agyeman-Yeboah, S. (2017). The Role of Financial Institutions in Housing Delivery in the Kumasi Metropolis of Ghana: An Institutional and Client Analysis. Journal of Economics and Sustainable Development, 8(14), 226-236.

Boamah, N. A. (2010). Housing Affordability in Ghana: A focus on Kumasi and Tamale. Journal, Ethiopian Studies, Environmental Vol, Management, 3(3), 1-11.

Boehm, Thomas P., and Alan M. Schlottmann. (2001). “Family Wealth Accumulation and the Housing Hierarchy: An Intertemporal Analysis." Working Paper.

Department for International Development (DfID). (2015). Urban infrastructure in Sub - Saharan Africa - harnessing land values, housing and transport.

Derban, W. K., Derban, D. K., Ibrahim, G., \& Rufasha, K. (2002). Microfinance for Housing for Low / Moderate-income Households In Ghana. In Presented at the Conference on Housing and Urban Development for Low Income Groups in Sub Saharan Africa. 22-26 July 2002 (pp. 1-20).

Djokoto, S. D., Dadzie, J., \& Ohemeng-Ababio, E. (2014). Barriers to Sustainable Construction in the Ghanaian Construction Industry: Consultants Perspectives. Journal of Sustainable Development, 7(1). https://doi.org/10.5539/jsd.v7n1p134

Flavin, M. and Yamashita, T., (2002). Owner-occupied housing and the composition of the household portfolio over the life cycle. American Economic Review, 9(2), 345-362.

Ghana Statistical Service, (2012). 2010 Population and Housing Census Final Results, Ghana Statistical Service, Accra, Ghana.

Giddings, S.W., (2007). Housing Challenges and Opportunities in Sub-Saharan Africa, International Housing Coalition, Washington DC, U.S.A.

Government of Ghana. (1992). The 1992 Constitution of the Republic of Ghana. https://doi.org/10.1017/ S0021855300011499

Griffith, M., \& Jefferys, P. (2013). Solutions for the housing shortage: How to build the 250,000 homes we need each year.

Kwofie, T. E., Adinyira, E., \& Botchway, E. (2011). Historical Overview of Housing Provision in the Pre and Post Independence Ghana. In In: Laryea, S., Leiringer, R. and Hughes, W. (Eds) Procs West Africa Built Environment Research (WABER) Conference, 19-21 July, Accra, Ghana, 541-557.

Lemo, T. (2007). Liberalization of the housing market and fiscal policy for effective mortgage creation and origination. A paper presented at the National Workshop of Association of Housing Corporations of Nigeria, Ota. October 23 - 24, 2007. 
Makinde, O.O., (2014). Housing delivery system, need and demand. Environment, Development and Sustainability, 16(1), 49-69

Ministry of Water Resources, Works and Housing. (2015). National Housing Policy. Accra: Ministry for Water Resources, Works and Housing.

Mukhtar, M .H. (2005). Conceptual issues in assessing housing needs in urban areas of developing countries. Journal of the Association of Architectural Educators in Nigeria, 4(1), 49-50

Nenova, T., (2010). Expanding housing finance to the underserved in South Asia: Market review and forward agenda. Washington: The World Bank.

Nicole, Beattie; Campbell, M. A. B. Y. (2010). Incremental Housing : Solutions to Meet the Global Urban Housing Challenge. Network Session - Global University Consortium - SIGUSMIT UN World Urban Forum, Brazil, March 2010, (March), $1-23$.

Sinai, T. and Souleles, N., (2005). Owner-occupied housing as a hedge against rent risk. Quarterly Journal of Economics 12 (1), 763-89.

Sodeinde, A. H. (2011). A Stimulus Plan For Affordable Housing Solutions In Emerging Nations.

Teasdale, S., Jones, P. A., \& Mullins, D. (2009). Connecting the dots : the potential for self-help housing to address homelessness. Management of the Housing Crisis.

Todd S., (2007). Urban Housing Demand. New Palgrave Dictionary of Economics. University of Pennsylvania. Wharton

Ubink, J. M., \& Quan, J. F. (2008). How to combine tradition and modernity? Regulating customary land management in Ghana. Land Use Policy, 25(2), 198-213. https://doi. org/10.1016/j.landusepol.2007.06.002

Ukwayi, J. K., Eja, E. E., Ojong, F. E., \& Otu, J. E. (2012). An Assessment of Housing Delivery in Nigeria: Federal Mortgage Bank Scenario. Canadian Social Science, 8(6), 68-74. https:// doi.org/10.3968/j.css.1923669720120806.1613

UN-Habitat., (2011). Ghana Housing Profile. United Nations Human Settlement Programme, Nairobi. Accessed at www. unhabitat.org

Vuyisani, M. (2003). Preview of housing finance systems in four different African countries: South Africa, Nigeria, Ghana and Tanzania

Wakely, P., \& Riley, E. (2011). CITIES WITHOUT SLUMS:The Case for Incremental Housing. Cities Alliance Policy Research and Working Papers. https://doi.org/10.1111/ctr.12522

Wapwera, S.D., Parsa, A. and Egbu, C., (2014). Financing low income housing in Nigeria. Charles Report Information from Pro Quest Westport.

Yeboah, E., \& Obeng-Odoom, F. (2010). " We are not the only ones to blame ": District Assemblies ' perspectives on the state of planning in Ghana. Commonwealth Journal of Local Governance, November 1(7), 78-98. Retrieved from https:/ / papers.ssrn.com/sol3/papers.cfm?abstract_id $=1743586$

Yeboah, I. E. A. (2005). Housing the Urban Poor in Twenty-First Century Sub-Saharan Africa: Policy Mismatch and a Way
Forward for Ghana. GeoJournal, 62(1-2), 147-161. https:/ / doi.org/10.1007/s10708-005-8182-x

Yin, R. K. (2003). Case study research: Design and methods (3rd ed.). Thousand Oaks, CA: Sage

Yorgri, E., Hong, L., Wen, C., \& Jamani, P. (2016). Research on Urban Low Income Housing Policy Delivery in Tamale, Ghana. In International Conference on Civil, architecture and Sustainable Development (CASD-2016) Dec.1-2, 2016 (pp. 1-5). London (UK). 
